\title{
BIODEGRADATION OF 2,4-DICHLOROPHENOXYACETIC ACID AND 4-CHLOROPHENOL IN CONTAMINATED SOILS BY Pseudomonas fluorescens strain HH
}

\author{
Ha Danh Duc*, Nguyen Thi Oanh, Nguyen Gia Hien \\ Dong Thap University, Dong Thap, Vietnam \\ Received 24 August 2018, accepted 5 March 2019
}

\begin{abstract}
Herbicides with 2,4-dichlorophenoxyacetic acid (2,4D) has been commonly used to control weeds and widely detected in environments. In this study, biodegradating activity of Pseudomonas fluorescens $\mathrm{HH}$ on 2,4D and 4-chlorophenol (4CP) in soil was carried out. The inoculation with Pseudomonas fluorescens $\mathrm{HH}$ in soils increased the degradation of $4 \mathrm{CP}$ and $2,4 \mathrm{D}$ by from $47.0 \%$ to $51.4 \%$ and from $38.4 \%$ to $47.4 \%$, respectively, compared to the degradation by autochthonous microorganisms. Pseudomonas fluorescens $\mathrm{HH}$ could degrade well 2,4D and 4CP in various soils, but the most efficient chemical removal was observed when they were in the loamy soil. Moreover, the efficiency of chemical degradation was significantly affected by the moisture contents with the highest performance of degradation at 10 and $20 \%$ soil moisture. Also, the addition of nitrogen $(\mathrm{N})$, phosphorous $(\mathrm{P})$ and potassium $(\mathrm{K})$ stimulated the dissipation rates. The determination of degradation pathway for 2,4D in Pseudomonas fluorescens $\mathrm{HH}$ indicated that 2,4-dichlorophenol (2,4DCP) and 4CP were formed as metabolites.
\end{abstract}

Keywords: Pseudomonas fluorescens HH, 2,4-dichlorophenoxyacetic acid, 4-chlorophenol, loamy soil, degradation.

Citation: Ha Danh Duc, Nguyen Thi Oanh, Nguyen Gia Hien, 2019. Biodegradation of 2,4-dichlorophenoxyacetic acid and 4-chlorophenol in contaminated soils by Pseudomonas fluorescens strain HH. Academia Journal of Biology, 41(3): 67-75. https://doi.org/10.15625/2615-9023/v41n3.13009.

*Corresponding author email: hadanhduc@gmail.com

(C2019 Vietnam Academy of Science and Technology (VAST) 


\section{INTRODUCTION}

Herbicides including 2,4D are commonly used to control weeds. Because of high agricultural application, 2,4D has been widely detected in environments. For example, the compound has been detected in groundwater (Williams et al., 1988; Kolpin et al., 2000), surface water (Frank and Logan, 1988), wastewater treatment plants (Hope et al., 2012), sediment (Konasewich et al., 1978; Klecka et al., 2010) and soil (Webber and Wang, 1995).

2,4D has been classified as a hormonal herbicide with level II by the World Health Organization (WHO). This chemical causes depression of the central nervous system and damage to the liver and kidneys of human and animals (Moody et al., 1992; Duffard et al., 1996; Mattsson et al., 1997; Charles et al., 2001; Kwangjick et al., 2001; Kim et al., 2005). While $2,4 \mathrm{D}$ acts as an active auxin at low concentrations, it causes changes of the normal pattern resulting in the death of plants at high concentrations (Harborne, 1988).

$2,4 \mathrm{D}$ is moderately mobile in soils, and the mobility depends on soil characteristics (Ordaz-Guillen et al., 2014). 2,4D exists predominantly as an anion which is adsorbed to positively charged sites on the edges of clay particles in soil preventing its cellular uptake and biodegradation (McGhee et al., 1999). The degradation of $2,4 \mathrm{D}$ in soil has been investigated in various laboratories (Jacobsen \& Pedersen, 1991; Bryant, 1992; Balajee \& Mahadevan, 1993; Entry et al., 1996; Chang et al., 1998; Cycoń et al., 2011; Musarrat et al., 2000; Chang et al., 2016; Xia et al., 2017). However, the degradation of 2,4D in various soil with different physico-chemical properties has not been conducted extensively.

Although 2,4D and also 4CP may be remediated by physical and chemical methods, the degradation by microorganisms is a major process for cleaning up the compounds. The biotransformation of $2,4 \mathrm{D}$ usually produced chlorophenols as intermediates (Bryant 1992; Chang et al., 1998; Robles-González et al., 2006; Wu et al., 2010; Yang et al., 2017). Chlorophenols are suspected to be carcinogens and mutagens, so they are also listed as hazardous substances (WHO, 1989). The use in industries and agricultural herbicides resulted in serious chlorophenols contamination in soil (Nowak \& Mrozik, 2018).

$P$. fluorescens $\mathrm{HH}$ which can aerobically utilize $2,4 \mathrm{D}$ as a sole carbon and energy source was isolated and its degradation ability in liquid medium was determined (Nguyen Thi Oanh et al., 2018). In this study, the chemical degradation of $2,4 \mathrm{D}$ and $4 \mathrm{CP}$ by $P$. fluorescens $\mathrm{HH}$ was investigated for various soil types with different components. Also, the effects of N, P, K and moisture content on the bioremediation of highly contaminated soils by $P$. fluorescens $\mathrm{HH}$ were examined.

\section{MATERIALS AND METHODS}

\section{Bacteria used for chemical degradation}

$P$. fluorescens $\mathrm{HH}$ isolated from soil can utilize 2,4D as the sole carbon (Nguyen Thi Oanh et al., 2018). The isolate has been deposited in the Culture Collection at the Center for Biochemical Analysis (Dong Thap University, Vietnam) under the deposition number DUCOANH2015-7C.

\section{Degradation of 2,4D and 4CP in contaminated soils}

The degradation of 2,4D and 4CP in soil was carried out according to the methods in a previous report (Duc, 2017) with slight modification. Soil samples were taken from a depth of $10-50 \mathrm{~cm}$ in some places in Dong Thap Province, Vietnam. Soil samples were then air-dried at room temperature (approximately $30^{\circ} \mathrm{C}$ ) until the weight became constant, then they were sieved through $2 \mathrm{~mm}$ mesh to remove large debris before assaying chemical components. The physical and chemical properties of each soil sample adjusted to unit dry soil weight are presented in table 1 . The soil types were classified based on the Soil Survey Division Staff (USA). Before the experiments, the concentrations of 2,4D and 4CP which might contaminate soils by farmers were analyzed, but no such chemicals were detected in all soil samples. 
Table 1. Physico-chemical characteristics of four dry soil samples

\begin{tabular}{|l|c|c|c|c|}
\hline Soil texture & Loamy sand & Sandy loam & Sandy clay loam & Loamy soil \\
\hline Granulometric properties $(\%)$ & 7.5 & 5.4 & 5.5 & 0.7 \\
\hline Coarse sand $(>0.2 \mathrm{~mm})$ & 77.4 & 65.5 & 33.7 & 34.4 \\
\hline Fine sand $(0.2-0.02 \mathrm{~mm})$ & 7.7 & 13.1 & 25.5 & 40.4 \\
\hline Silt $(0.02-0.002 \mathrm{~mm})$ & 7.9 & 16.0 & 35.3 & 24.5 \\
\hline Clay $(<0.002 \mathrm{~mm})$ & 6.3 & 6.4 & 6.1 & 6.2 \\
\hline Agrochemical properties & 1.3 & 2.7 & 3.5 & 4.4 \\
\hline $\mathrm{pH}$ & 0.08 & 0.17 & 0.30 & 0.44 \\
\hline Total C $(\%)$ & 33.7 & 55.6 & 34.4 & 28.8 \\
\hline Total N $(\%)$ & 6.6 & 30.1 & 18.8 & 8.4 \\
\hline $\mathrm{P}_{2} \mathrm{O}_{5}(\mathrm{ppm})$ &
\end{tabular}

$200 \mathrm{~g}$ of each soil type were placed in a 500-mL glass jar covered with aluminum foil. The soil samples were spiked with $100 \mathrm{mg}$ $2,4 \mathrm{D}$ or $4 \mathrm{CP}$ per $1.0 \mathrm{~kg}$ dry soil. Then, the soil samples were inoculated with the cell suspension of $P$. fluorescens $\mathrm{HH}$ to give an initial population of $10^{6}$ cells/g dry soil. The jars were then incubated at room temperature (approximately $30^{\circ} \mathrm{C}$ ) in the dark. To determine chemical degradation in various soil types and to evaluate the effects of NKP on degradation, soil moisture was maintained at $20 \%$ of the water-holding capacity by sprinkling sterile water. For the experiments on the effects of the moisture content on substrate degradation, soil moisture was adjusted from $5 \%$ to $40 \%$. The jars were manually shaken every 5 -days to enhance soil $\mathrm{O}_{2}$ availability. The controls without inoculation with $P$. fluorescens $\mathrm{HH}$ were run in parallel. The bacterial inoculum was prepared by cultivation of $P$. fluorescens $\mathrm{HH}$ in LB medium for $12 \mathrm{hr}$. The culture was centrifuged for $5 \mathrm{~min}$ at $12,000 \mathrm{rpm}$, washed twice with phosphate buffer (50 mM, pH 7.0) and resuspended in sterile water.

To determine chemical degradation, chemicals were extracted from $5 \mathrm{~g}$ soil with $15 \mathrm{~mL}$ methanol (> 99\%) twice (Cotterill 1980). The extract was concentrated and filtered through a $0.22-\mu \mathrm{m}$ syringe filter. The mean recovery of 2,4D from loamy sand, sandy loam, sandy clay loam and loam was
$96.4 \%, 95.5 \%, 93.3$ and $97.7 \%$, respectively. 4CP recovered from these soils was $95.5 \%$, $93.3 \%, 91.4$ and $96.3 \%$, respectively.

\section{Effects of NPK on degradation of 2,4D and 4CP}

The effects of NPK on degradation of $2,4 \mathrm{D}$ and $4 \mathrm{CP}$ were conducted according to the methods described by McGhee et al. (1999). Soil samples (200 g of each type) were placed in a $500-\mathrm{mL}$ glass jar and amended with nitrogen $\left(\mathrm{NH}_{4} \mathrm{NO}_{3}, 2.5 \mathrm{mg} / \mathrm{g}\right)$, phosphorus $\left(\mathrm{NaHPO}_{4} .2 \mathrm{H}_{2} \mathrm{O}, 3.5 \mathrm{mg} / \mathrm{g}\right)$ and potassium $\left(\mathrm{K}_{2} \mathrm{CO}_{3}, 4.5 \mathrm{mg} / \mathrm{g}\right)$ which are the same amount and ratio of $\mathrm{N}, \mathrm{P}$ and $\mathrm{K}$ of the commercial combined NPK fertilizer. Samples were taken after 15 days of incubation to determine the degradation of chemical degradation.

\section{Analytical methods}

The 2,4D and 4CP concentrations were determined using HPLC equipped with a 4.6 mmU25 cm Ultrasphere $\mathrm{C} 18$ column (Beckman). The mobile phase was the mixture of methanol, water and acetic acid $(40 / 57 / 3, \mathrm{v} / \mathrm{v})$ which run at a flow rate of 1.0 $\mathrm{mL} / \mathrm{min}$. GC-MS with HP-5MS column (30 m $\times 0.25 \mathrm{~mm} \times 0.25 \mathrm{~mm}$; Agilent, Palo Alto, CA, USA) was used to determine metabolites of 2,4D degradation. The UV detection was at $283 \mathrm{~nm}$. The process was carried out using an electron ionization (EI) mode $(70 \mathrm{eV})$ with an Agilent gas chromatograph equipped with an 
MS detector (5975C). Temperatures of the injection port and the detector were controlled at $250^{\circ} \mathrm{C}$ and $280^{\circ} \mathrm{C}$, respectively. The temperatures of the program were held at $50^{\circ} \mathrm{C}$ for $7 \mathrm{~min}$, raised $5^{\circ} \mathrm{C}$ per min to $280^{\circ} \mathrm{C}$ and finally held at this temperature for $5 \mathrm{~min}$. During the operation process, Helium $(1 \mathrm{~mL} / \mathrm{min})$ was used as the carrier gas. The HPLC and GC-MS results were compared with retention times and authentic standards of known compounds.

\section{Statistical analysis}

Data were calculated and shown as the mean \pm one standard deviation from at least in triplicate experiments. The SPSS software program version 22.0 was used to analyze variance, and significant differences ( $p<$ 0.05 ) were calculated using Duncan's multiple range test.

\section{RESULTS AND DISCUSSION}

\section{Degradation of 2,4D and $4 \mathrm{CP}$ in various soils}

The degradation of 2,4D and 4CP was carried out in various soil types which represent the soil types commonly used for cultivation in the Mekong Delta. The remediation rates and adaptation ability of $P$. fluorescens $\mathrm{HH}$ to different constituents were compared in those soil samples. The degradation of the substrates was carried out in sterile and non-sterile soils. Table 2 showed that the degradation rates of $2,4 \mathrm{D}$ in soils inoculated with bacteria were, regardless of the types of soil samples, significantly higher than those in soils without inoculation. The degradation rates of $4 \mathrm{CP}$ and $2,4 \mathrm{D}$ by $P$. fluorescens $\mathrm{HH}$ were from 47.0 to $51.4 \%$ and from $38.4 \%$ to $47.4 \%$ higher compared to the degradation in control by native microorganisms, respectively (table 2). Significantly higher amounts of 2,4D were degraded in non-sterile soils compared with in sterile soils illustrating that $2,4 \mathrm{D}$ and $4 \mathrm{CP}$ were also degraded by indigenous microorganisms, and $P$. fluorescens $\mathrm{HH}$ cooperated well with autochthonous microorganisms. The 2,4D degradation by indigenous microorganisms in soils was reported previously (Comeau et al., 1993; McGhee et al., 1999). The biotic and abiotic factors of soils affect the success of biodegradation. The survival and growth of inoculated bacteria play a key role in bioaugmentation. The physico-chemical environmental parameters of soils also strongly influence the mineralization process of organic contaminants.

Table 2. Degradation of 2,4D and 4CP in various soil types and the roles of inoculation of $P$. fluorescens $\mathrm{HH}$ on degradation. Soils were inoculated with $100 \mathrm{mg} / \mathrm{kg}$ of chemical substrates. Soil samples were incubated for 15 days

\begin{tabular}{|c|c|c|c|c|c|}
\hline \multirow{2}{*}{ Soils } & \multirow{2}{*}{ Substrates } & \multicolumn{4}{|c|}{ Substrate degradation $(\%)^{*}$} \\
\hline & & Loamy sand & Sandy loam & Sandy clay loam & Loamy soil \\
\hline \multicolumn{6}{|c|}{ None-inoculated soils } \\
\hline \multirow{2}{*}{ Sterile soil } & $2,4 \mathrm{D}$ & $4.8 \pm 0.9^{\mathrm{aA}}$ & $5.5 \pm 0.8^{\mathrm{aA}}$ & $7.8 \pm 1.0^{\mathrm{aB}}$ & $5.5 \pm 1.0^{\mathrm{aA}}$ \\
\hline & $4 \mathrm{CP}$ & $3.9 \pm 0.5^{\mathrm{aA}}$ & $4.2 \pm 0.6^{\mathrm{aA}}$ & $8.8 \pm 1.1^{\mathrm{aC}}$ & $6.4 \pm 1.2^{\mathrm{aB}}$ \\
\hline \multirow{2}{*}{$\begin{array}{l}\text { None- } \\
\text { sterile soil }\end{array}$} & $2,4 \mathrm{D}$ & $10.3 \pm 1.6^{\mathrm{aA}}$ & $10.2 \pm 1.4^{\mathrm{aA}}$ & $14.5 \pm 2.6^{\mathrm{aB}}$ & $17.8 \pm 3.2^{\mathrm{bC}}$ \\
\hline & $4 \mathrm{CP}$ & $8.4 \pm 1.8^{\mathrm{aA}}$ & $13.4 \pm 1.7^{\mathrm{aB}}$ & $18.0 \pm 2.2^{\mathrm{aC}}$ & $21.1 \pm 3.5^{\mathrm{bC}}$ \\
\hline \multicolumn{6}{|c|}{ Soils inoculated with bacteria } \\
\hline \multirow{2}{*}{ Sterile soil } & $2,4 \mathrm{D}$ & $48.7 \pm 5.9^{\mathrm{bA}}$ & $55.7 \pm 6.0^{\mathrm{bAB}}$ & $60.7 \pm 7.4^{\mathrm{bAB}}$ & $65.2 \pm 8.2^{\mathrm{cC}}$ \\
\hline & $4 \mathrm{CP}$ & $55.5 \pm 6.4^{\mathrm{bcA}}$ & $60.4 \pm 6.9^{\mathrm{bcAB}}$ & $65.7 \pm 7.5^{\mathrm{bcAB}}$ & $72.5 \pm 7.0^{\mathrm{cdB}}$ \\
\hline \multirow{2}{*}{$\begin{array}{l}\text { None- } \\
\text { sterile soil }\end{array}$} & $2,4 \mathrm{D}$ & $53.7 \pm 6.2^{\mathrm{bcA}}$ & $65.0 \pm 6.4^{\mathrm{cdAB}}$ & $71.4 \pm 7.9^{\mathrm{cdB}}$ & $73.4 \pm 6.2^{\mathrm{cdB}}$ \\
\hline & $4 \mathrm{CP}$ & $58.4 \pm 6.5^{\mathrm{cA}}$ & $70.4 \pm 7.9^{\mathrm{dAB}}$ & $77.0 \pm 8.4^{\mathrm{dB}}$ & $80.7 \pm 5.7^{\mathrm{dB}}$ \\
\hline
\end{tabular}

Note: "Different capital superscript letters (A, B and C) and small superscript letters (a, b, c and d) indicate statistically significant differences $(p<0.05)$ among treatments within a line and a column, respectively. 
The soil texture and soil nutrients can affect the degradation rates. The degradation was effective in loamy soil, while it was low in loamy sand (table 2). The nutrients available in soils probably accounted for the degradation rates. The loam and sandy clay loam with higher carbon and nitrogen (table 1) resulted in higher degradation rates. Phenol degradation by Pseudomonas sp. JS150 was significantly faster in soils with higher organic matter content (Mrozik et al., 2011). Clay with fine grains has low permeability and retarded oxygen transport in the soil. However, the degradation rate in the sandy clay loam in this study was not low compared to the rates in other soil types. This probably is because sand grains in this soil enhanced the permeability. Related to this, the clay content in soil did not affect the degradation of 2,4D (Boivin et al., 2005).

\section{Effects of NPK on 2,4D and 4CP degradation}

To enhance crop yield, farmers not only use fertilizers, but also use herbicides. The main components of inorganic fertilizers are $\mathrm{N}, \mathrm{P}$ and $\mathrm{K}$. The degradation of $2,4 \mathrm{D}$ and $4 \mathrm{CP}$ with the supplementation of these nutrients shown in table 3 was higher than those in soils without supplementation of nutrients presented shown in table 2. Nutrients may be needed to manipulate soil conditions to enhance inoculum survival, proliferation and activities of microorganisms (Greer \& Shelton, 1992). Nevertheless, the degradation of $2,4 \mathrm{D}$ and $4 \mathrm{CP}$ was not complete in this study. 2,4D may be undergone the adsorption and/or reactions with clays and humics in soil reducing bioavailability to microorganisms (Ogram et al., 1985; Greer \& Shelton, 1992; McGhee et al., 1999) probably resulting in incomplete biodegradation.

Table 3. The degradation of 2,4D and 4CP with the supplementation of NPK

\begin{tabular}{|l|c|c|c|c|}
\hline \multirow{2}{*}{ Substrates } & \multicolumn{4}{|c|}{ Substrate degradation $(\%)^{*}$} \\
\cline { 2 - 5 } & Loamy sand & Sandy loam & Sandy clay loam & Loamy soil \\
\hline None-inoculated soils & $17.7 \pm 2.7^{\mathrm{aA}}$ & $20.3 \pm 3.6^{\mathrm{aA}}$ & $22.3 \pm 3.2^{\mathrm{aAB}}$ & $24.4 \pm 5.5^{\mathrm{aB}}$ \\
\hline 2,4D & $27.0 \pm 3.8^{\mathrm{aA}}$ & $28.3 \pm 3.8^{\mathrm{aA}}$ & $28.3 \pm 3.8^{\mathrm{aA}}$ & $33 . \pm 3.7^{\mathrm{bA}}$ \\
\hline 4CP & \multicolumn{5}{|l|}{} \\
\hline Soils inoculated with bacteria & $62.3 \pm 7.4^{\mathrm{bA}}$ & $73.3 \pm 7.2^{\mathrm{bAB}}$ & $80.3 \pm 5.0^{\mathrm{bBC}}$ & $90.4 \pm 3.0^{\mathrm{cC}}$ \\
\hline $2,4 \mathrm{D}$ & $67.3 \pm 7.3^{\mathrm{bA}}$ & $75.3 \pm 7.4^{\mathrm{bAB}}$ & $85.0 \pm 6.6^{\mathrm{bBC}}$ & $92.6 \pm 2.2^{\mathrm{cC}}$ \\
\hline 4CP &
\end{tabular}

Note: ${ }^{*}$ Different capital superscript letters (A, B and C) and small superscript letters (a, b, c and d) indicate statistically significant differences $(p<0.05)$ among treatments within a line and a column, respectively.

\section{Effects of soil moisture on the degradation of 2,4D and 4CP by $P$. fluorescens $\mathrm{HH}$}

The loamy soil which showed relatively effective degradation described above was used in this experiment. The optimum moisture value of soils affecting on biodegradation depends on pore size distribution and soil texture. In this experimental condition using loamy soil, the degradation rates of $2,4 \mathrm{D}$ and $4 \mathrm{CP}$ was highest at the 10 and $20 \%$ of moisture contents (Fig. 1). The degradation rates of $4 \mathrm{CP}$ and 2,4D in loamy soil with $40 \%$ moisture content was slightly lower than those in 10 and $20 \%$ moisture but statistically not different with each other. The low level of moisture content $(5 \%)$ and excess water (more than 20\%) decreased the degradation efficiency. The restriction of water content which resulted in low degradation might be due to the reduction of microbial activities and chemical diffusion. Meanwhile, the excess water in soil may interrupt oxygen 
diffusion and produce an unwanted leachate resulting in the decrease of degradation (Schjønning et al., 2011). For 4CP degradation, Cho et al., (2000) reported that about 10 days are required to reach complete degradation by indigenous microorganisms at the initial concentration of $60 \mathrm{mg} / \mathrm{kg}$ in loamy sand with the optimal moisture contents of 10 and $15 \%$. In another report, the inoculation with Pseudomonas sp. CF600 increased 4CP degradation in soil (Nowak \& Mrozik, 2018).

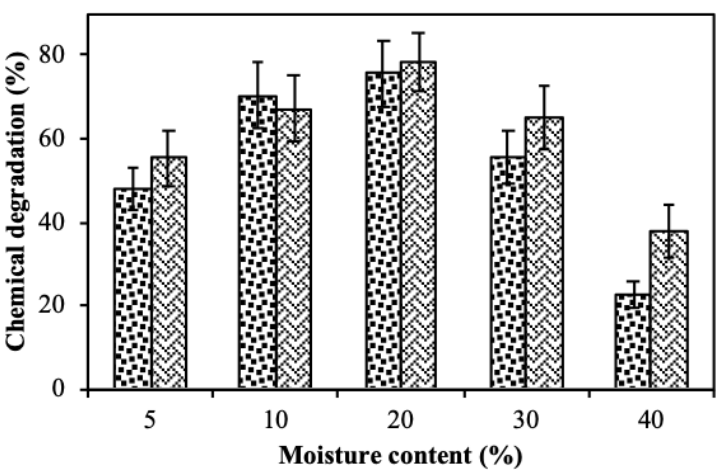

Figure 1. Effects of moisture content on degradation of 2,4D (중) and 4CP (图) in sterile loamy soil inoculated with $P$. fluorescens $\mathrm{HH}$. Individual chemicals were supplemented at $100 \mathrm{mg} / \mathrm{kg}$ dry soil

\section{Degradation pathways for 2,4D in Pseudomonas fluorescens $\mathrm{HH}$}

The degradation products of 2,4D in loamy soil were analyzed based on the results of HPLC and GC/MS profiles. During the transformation of $2,4 \mathrm{D}$, a product was proposed to be 2,4DCP $(\mathrm{m} / \mathrm{z}, 162,164,98,63$ in GC/MS), suggesting that the side-chain removal was the first step of the process. Another metabolite with HPLC retention time of $14.2 \mathrm{~min}$ and $\mathrm{m} / \mathrm{z} 128,130,64 \mathrm{in}$ GC/MS analyses was identified to be $4 \mathrm{CP}$. The concentrations of $4 \mathrm{CP}$ produced during the degradation of 2,4D were always higher than those of 2,4DCP (Fig. 2). 4CP is assumed to be oxidized further; however, other metabolites such as phenolic compounds were not detected in soil samples probably because their concentrations were so small or they were immediately transformed in the degradation process. From these results, the plausible complete degradation pathway for $2,4 \mathrm{D}$ is proposed in figure 3 .

As for the supportive evidence, $P$. cepacia BRI6001 degraded 2,4D to produce 2,4DCP (Greer et al., 1990). Similarly, Achromobacter sp. LZ35 transformed 2,4D to 2,4DCP, although 4CP was not detected as the degradation product (Xia et al., 2017). In another study, 2,4D was transformed to 4CP by Azotobacter sp. SSB81 (Gauri et al., 2012).

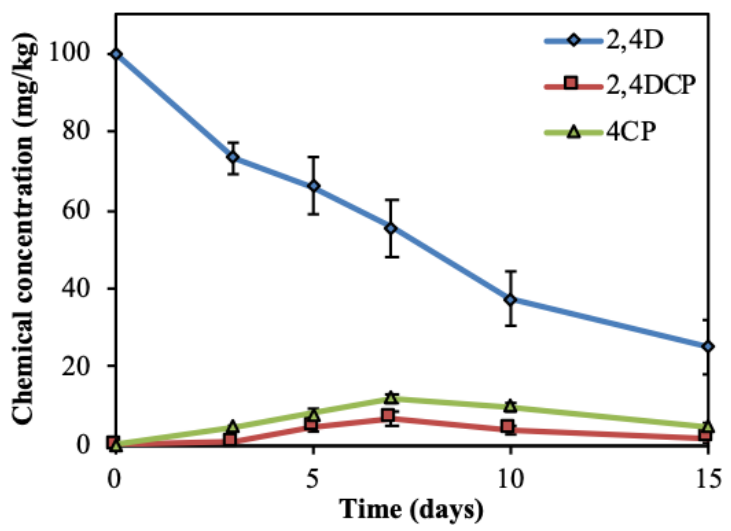

Figure 2. Degradation of 2,4D by

Pseudomonas fluorescens $\mathrm{HH}$ in loamy soil and the formation of 2,4DCP and 4CP during the degradation<smiles>O=C(O)COc1ccc(Cl)cc1Cl</smiles>

Figure 3. Proposed the degradation pathway for 2,4D in Pseudomonas fluorescens $\mathrm{HH}$ 


\section{CONCLUSION}

$P$. fluorescens $\mathrm{HH}$ augmented degradation of $2,4 \mathrm{D}$ and $4 \mathrm{CP}$ in four soil types with different characteristics. The loamy soil was favorable for the degradation of 2,4D and $4 \mathrm{CP}$. Soil conditions such as moisture and nutrients also affected the degradation of those chemicals by $P$. fluorescens $\mathrm{HH}$. 2.4D is supposed to be degraded to 2,4DCP and then $4 \mathrm{CP}$. This study provides knowledge about better conditions to augment biodegradation by $P$. fluorescens $\mathrm{HH}$.

Acknowledgements: This work was done by the research group. Authors are thankful to Dong Thap University for all the supports.

\section{REFERENCES}

Balajee S., Mahadevan A., 1993. Biodegradation of 2,4dichlorophenoxyacetic acid in soil by Azotobacter chroococcum. Toxicological \& Environmental Chemistry, 39(3-4): 169-172.

Boivin A., Amellal S., Schiavon M., van Genuchten, M. T., $2005.2,4-$ Dichlorophenoxyacetic acid (2,4D) sorption and degradation dynamics in three agricultural soils. Environmental Pollution, 138(1): 92-99.

Bryant F. O., 1992. Biodegradation of 2,4Dichlorophenoxyacetic acid and 2,4,5trichlorophenoxyacetic acid by dichlorophenol-adapted microorganisms from freshwater, anaerobic sediments. Applied Microbiology and Biotechnology, 38(2): 276-281.

Chang B. V., Liu J. Y., Yuan S. Y. 1998. Dechlorination of 2,4Dichlorophenoxyacetic acid and 2,4,5trichlorophenoxyacetic acid in soil. Science of The Total Environment, 215(21): $1-8$.

Chang Y. C., Reddy M. V., Umemoto H., Sato Y., Kang M. H., Yajima Y., Kikuchi S., 2016. Bio-augmentation of Cupriavidus sp. CY-1 into 2,4D contaminated soil: microbial community analysis by culture dependent and independent techniques. PLOS ONE 10, e0145057.

Charles J. M., Hanley T. R., Wilson R. D., van Ravenzwaay B., Bus J. S., 2001. Development toxicity studies in rats and rabbits on 2,4-Dichlorophenoxyacetic acid and its forms. Toxicological Sciences, 60(1):121-131.

Cho Y. G., Rhee S. K., Lee S. T., 2000. Effect of soil moisture on bioremediation of chlorophenol-contaminated soil. Biotechnology Letters, 22(110): 915-919.

Comeau Y., Greer C. W., Samson R., 1993. Role of inoculum preparation and density on the bioremediation of 2,4-D contaminated soil by bioaugmentation. Applied Microbiology and Biotechnology, 38(5): 681-687.

Cotterill E. G., 1980. The efficiency of methanol for the extraction of some herbicide residues from soil. Pesticide Science, 11: 23-28.

Cycoń M., Żmijowska A., Piotrowska-Seget Z., 2011. Biodegradation kinetics of 2,4D by bacterial strains isolated from soil. Central European Journal of Biology, 6(2): 188-198.

Duc H. D., 2017. Degradation of chlorotoluenes by Comamonas testosterone KT5. Applied Biological Chemistry, 60(4): 457-465.

Duffard R., Garcia G., Rosso S., Bortolozzi A., Madariaga M., di Paolo O., Evangelista de Duffard A. M., 1996. Central nervous system myelin deficit in rats exposed to 2,4-dichlorophenoxyacetic acid throughout lactation. Neurotoxicology and Teratology, 18(6): 691-696.

Entry J. A., Donnelly P. K., Emmingham W. H., 1996. Mineralization of atrazine and $2,4 \mathrm{D}$ in soils inoculated with Phanerochaete chrysosporium and Trappea darkeri. Applied Soil Ecology, 3(1): 85-90. 
Frank R., Logan L., 1988. Pesticide and industrial chemical residues at the mouth of the grand, Saugeen and Thames rivers, Ontario, Canada, 1981-85. Archives of Environmental Contamination and Toxicology, 17(6): 741-754.

Gauri S. S., Mandal S. M., Dey S., Pati B. R., 2012. Biotransformation of p-coumaric acid and 2,4-Dichlorophenoxy acetic acid by Azotobacter sp. strain SSB81. Bioresource Technology, 126: 350-353.

Greer C. W., Hawari J., Samson R., 1990. Influence of environmental factors on 2,4Dichlorophenoxyacetic acid degradation by Pseudomonas cepacia isolated from peat. Archives of Microbiology, 154(4): 317-322.

Greer L. E., Shelton D. R., 1992. Effect of inoculant strain and organic matter content on kinetics of 2,4-Dichlorophenoxyacetic acid degradation in soil. Applied and Environmental Microbiology, 58(5): 1459-1465.

Harborne J. B., 1988 Introduction to Ecological Biochemistry. San Diego, California: Academic Press. ISBN 012324683-0.

Hope B. K., Pillsbury L., Boling B., 2012. A state-wide survey in Oregon (USA) of trace metals and organic chemicals in municipal effluent. Science of The Total Environment, 417-418: 263-272.

Jacobsen C. S., Pedersen J. C., 1991. Growth and survival of Pseudomonas cepacia DBO1(pRO101) in soil amended with 2,4Dichlorophenoxyacetic acid. Biodegradation, 2(4): 245-252.

Kim H. J., Park Y. I., Dong M. S., 2005. Effects of 2,4D and DCP on the DHTinduced androgenic action in human prostate cancer cells. Toxicological Sciences, 88(1): 52-59.

Klecka G., Persoon C., Currie R., 2010. Chemicals of emerging concern in the Great Lakes Basin: an analysis of environmental exposures. Reviews of
Environmental Contamination and Toxicology, 207: 1-93.

Kolpin D., Barbash J., Gilliom R., 2000. Pesticides in Ground Water of the United States, 1992-1996, 38.

Konasewich D., Traversy W., Zar H., 1978. Great Lakes water quality status report on organic and heavy metal contaminants in the Lakes Erie, Michigan, Huron and Superior Basins to the implementation committee of the Great Lakes Water Quality Board. International Joint Commission (IJC) Digital Archive.

Kwangjick L., Johnson V. J., Barry R., Blakley B. R., 2001. The effect of exposure to a commercial 2,4D formulation during gestation on the immune response in CD-1 mice. Toxicology, 165(1): 39-49.

Mattsson J., Charles J., Yano B., Cunny L., Wilson R., Bus J., 1997. Single-dose and chronic dietary neurotoxicity screening studies on 2,4-Dichlorophenoxyacetic acid in rats. Fundamental and Applied Toxicology, 40(1): 11-119.

McGhee I., Sannino F., Gianfreda L., Burns R. G., 1999. Bioavailability of 2,4D sorbed to a chlorite like complex. Chemosphere, 39(2): 285-291.

Moody R. P., Wester R. C., Melendres J. L., Maibach H. I., 1992. Dermal absorption of the phenoxy herbicide 2,4D dimethylamine in humans: effect of DEET and anatomic site. Journal of Toxicology and Environmental Health, 36(3): 241-250.

Mrozik A., Miga S., Piotrowska-Sege Z., 2011. Enhancement of phenol degradation by soil bioaugmentation with Pseudomonas sp. JS150. Journal of Applied Microbiology, 111(6): 1357-1370.

Musarrat J., Bano N., Rao R. A. K., 2000. Isolation and characterization of 2,4Dichlorophenoxyacetic acid-catabolizing bacteria and their biodegradation efficiency in soil. World Journal of Microbiology and Biotechnology, 16(5): 495-497. 
Nguyen Thi Oanh, Ha Danh Duc, Tran Dat Huy, Nguyen Gia Hien, Nguyen Thi Huynh Nhu, 2018. Degradation of 2,4Dichlorophenoxyacetic acid by Pseudomonas fluorescens Strain $\mathrm{HH}$. Academia Journal of Biology, 2018, 40(3): 65-73. https://doi.org/ 10.15625/2615-9023/v40n3.12694.

Nowak A., Mrozik A., 2018. Degradation of 4-chlorophenol and microbial diversity in soil inoculated with single Pseudomonas sp. CF600 and Stenotrophomonas maltophilia KB2. Journal of Environmental Management, 215: 216-229.

Ogram A. V., Jessup R. E., Ou L. T., Rao P. S., 1985. Effects of sorption on biological degradation rates of $(2,4-$ Dichlorophenoxy) acetic acid in soils. Applied and Environmental Microbiology, 49(3): 582-587.

Ordaz-Guillen Y., Galindez-Maye, C. J., Ruiz-Ordaz N., Juarez-Ramirez C., Santoyo-Tepole F., and Ramos-Monroy O., 2014. Evaluating the degradation of the herbicides picloram and 2,4D in a compartmentalized reactive biobarrier with internal liquid recirculation. Environmental Science and Pollution Research International, 21(14): 8765-8773.

Robles-González I., Ríos-Leal E., FerreraCerrato R., Esparza-García F., Rinderkenecht-Seijas N., Poggi-Varaldo H. M., 2006. Bioremediation of a mineral soil with high contents of clay and organic matter contaminated with herbicide 2,4Dichlorophenoxyacetic acid using slurry bioreactors: Effect of electron acceptor and supplementation with an organic carbon source. Process Biochemistry, 41(9): 1951-1960.
Schjønning P., Thomsen I. K., Petersen S. O., Kristensen K., Christensen B. T., 2011. Relating soil microbial activity to water content and tillage-induced differences in soil structure. Geoderma, 163, 256e264.

Soil Survey Division Staff (1993). Soil survey manual. United States Department of Agriculture. pp. 63-65. Retrieved 30 August 2014.

Webber M. D., Wang C., 1995. Industrial organic compounds in selected Canadian soils. Canadian Journal of Soil Science, 75(4): 513-524.

WHO, 1989. Chlorophenols other than pentachlorophenol, Environmental Health Criteria 93, World Health Organization.

Williams W. M., Holden P. W., Parsons D. W., Lorber M. N., 1988. Pesticides in Groundwater Data Base 1988 Interim Report, Office Pesticide Programs, U.S. Environmental Protection Agency, Washington, D. C. 37 pp.

Wu C. Y., Zhuang L., Zhou S. G., Li F. B., Li X. M., 2010. Fe(III)-enhanced anaerobic transformation of 2,4Dichlorophenoxyacetic acid by an ironreducing bacterium Comamonas koreensis CY01. FEMS Microbiology Ecology, 71(1): 106-113.

Xia Z. Y., Zhang L., Zhao Y., Yan X., Li S. P., Gu T., Jiang J. D., 2017. Biodegradation of the herbicide 2,4Dichlorophenoxyacetic acid by a new isolated strain of Achromobacter sp. LZ35. Current Microbiology, 74(2): 193-202.

Yang Z., Xu X., Dai M., Wang L., Shi X., Guo R., 2017. Rapid degradation of 2,4-Dichlorophenoxyacetic acid facilitated by acetate under methanogenic condition. Bioresour Technology, 232: 146-151. 